\title{
Land Use/Cover and Naturalness Changes for Watershed Environmental Management (Southeastern Brazil)
}

\author{
Rômulo Theodoro Costa',2, Camila Francisco Gonçalves', Angela Terumi Fushita ${ }^{3}$, \\ José Eduardo dos Santos ${ }^{1,2}$ \\ ${ }^{1}$ Analysis and Environmental Planning Laboratory, Universidade Federal de São Carlos (UFSCar), São Carlos, Brazil \\ ${ }^{2}$ Programa de Pós-Graduação em Ecologia e Recursos Naturais (PPGERN), Universidade Federal de São Carlos (UFSCar), \\ São Carlos, Brazil \\ ${ }^{3}$ Center for Engineering, Modeling and Applied Social Sciences, Universidade Federal do ABC (UFABC), Santo André, Brazil \\ Email: romulothcosta@gmail.com,djes@ufscar.br, angela.fushita@ufabc.edu.br
}

How to cite this paper: Costa, R.T., Gonçalves, C.F., Fushita, A.T. and dos Santos, J.E. (2017) Land Use/Cover and Naturalness Changes for Watershed Environmental Management (Southeastern Brazil). Journal of Geoscience and Environment Protection, $5,1-14$.

https://doi.org/10.4236/gep.2017.511001

Received: August 23, 2017

Accepted: October 31, 2017

Published: November 3, 2017

Copyright () 2017 by authors and Scientific Research Publishing Inc. This work is licensed under the Creative Commons Attribution International License (CC BY 4.0).

http://creativecommons.org/licenses/by/4.0/

\begin{abstract}
Driving forces on the landscape require regional management and/or local actions, together with other external factors. To operationalize this approach, this paper carried out a comparative analysis of the naturalness dynamics of the Jacaré-Guaçu and Jacaré-Pepira watershed, based on land use/cover changes and a structural indicator of the landscape, over the 10-year (2004-2014), as support opportunities for improving its environmental planning and management. Land use/cover dynamics were obtained based on screen digitizing of LandSat imagery, using polygon manual digitalization. Naturalness scenarios of the watersheds, over the 10-year (2004-2014), were obtained based on Urbanity Indicator, which evaluates how much the natural landscapes are dominated by altered systems. The total area of watersheds showed a predominantly scenario, induced by anthropogenic agricultural and non-agricultural expansion areas, mainly by conversion of other land use/cover types in sugarcane cultivation. Despite the increase in natural vegetation areas, over the 10-year (2004-2014), Jacaré-Guaçu and Jacaré-Pepira watersheds are far from a sustainable condition. However Jacaré-Guaçu watershed presents a scenario of more committed naturalness due to the increase in Urbanity Index values $\geq 0.7$. The historical process of land use occupation for agricultural production remains the main driving force of naturalness changes, occupying more than $70 \%$ of the total area of watersheds. These results have significant implications for fast urbanizing municipalities in providing key information about long term land use impact on the watershed structure and function, making it possible for policy makers, scientists and
\end{abstract}


stakeholders to identify land uses which are hindered or enhanced under various scenarios of land use change over the time, and making it possible to explore the trade-offs between them to improve watershed management.

\section{Keywords}

Land Use Changes, Urbanity Index, Loss Natural Capital, Watershed Sustainable Management

\section{Introduction}

The conversion of natural landscapes into cultural landscapes has been transforming a significant part of earth's surface. Human modification in land use/cover appeared as unprecedented in global scale in the last fifty years [1] [2].

Land use/cover is one of the most important drivers of change that directly affects biodiversity in understanding the interactions between human activities and the environment [3]. Land use/cover as a driver of change involves a dilemma: on the one hand, land use practices are essential in providing natural resources to support human needs; on the other hand, some land use trajectories result in environmental degradation and losses of ecosystem services [4] [5] [6].

This process is quite common in developing countries, where land use/cover changes resulting from socio-economic development have caused serious environmental problems such as landscape fragmentation and loss of naturalness [1] [7]. The naturalness level relates the similarity of a current ecosystem state to its natural state, a primary prerequisite for the preservation of biodiversity [8]. A low level of naturalness is related to degradation and loss of forest biodiversity [5] in all its forms and levels of organization [8].

Land conversion took place through increasing agriculture and urbanization affect, significantly energy flows, biogeochemical cycles, biodiversity and climatic conditions at local and/or regional scales [9]. All these changes are considered as driver attributes to global change [10], resulting in changes to ecosystem services, thereby affecting human well-being [3].

Structural indicators of the landscape are fundamental to understand the risks and threats of land use/cover concerning land use sustainability, resulting in quantifiable information that reflects environmental and natural resources conditions, and their relations with anthropogenic activities [2] [11]. Ecological indicators specifically deal with functions and processes of the ecosystem, while environmental and/or sustainability indicators incorporate specific aspects of ecosystems, as well as economic and social factors [2] [6] [11] [12]. This pool can provide essential information about current and historical conditions and the interactions between nature and society, which can be disseminated to the scientific community, the general public and decision makers [13].

Studies aimed at the characterization and diagnosis of landscapes under influence 
from the impact of land use/cover changes [2] [13] have used GISs since they are tools that facilitate activities in large areas, with less subjective results, in less time, replicable and more accurate [14].

In this study, a comparative analysis of the naturalness dynamics of the Jacaré-Guaçu and Jacaré-Pepira watersheds was carried out, based on dynamics of land use/cover changes and a structural indicator of the landscape, over the 10 years (2004-2014), as support opportunities for improvement its environmental management. Specifically, the study attempted to discover if: 1) Naturalness showed a significant difference into and between the Jacaré-Guaçu and Jacaré-Pepira watersheds due to the spatial and temporal land use/cover changes over the 10 years (2004-2014);2) The structural indicator of the landscape was efficient in identifying naturalness changes in the Jacaré-Guaçu and Jacaré-Pepira watersheds as a result of the spatial and temporal land use/cover changes.

\section{Material and Methods}

\subsection{Study Area}

The total area of study covers an extension of 683,150 ha, equivalent to the amount areas of the Jacaré-Guaçu and Jacaré-Pepira watersheds with areas of 416,800 ha and 266,350 ha, respectively. The study area is located between $21^{\circ} 37^{\prime} / 22^{\circ} 31^{\prime}$ south latitude and $47^{\circ} 43^{\prime} / 49^{\circ} 02^{\prime}$ west longitude, encompassing around $58 \%$ of the Tiete-Jacaré watershed's area (UGRHI 13). The total study area covers 22 municipalities of the eastern-central region of São Paulo state, of which only sixteen of their urban perimeters can be found on the watershed limits (Figure 1).

Four protected areas are within the Jacaré-Guaçu and Jacaré-Pepira watershed limits: two Integral Protection areas (Itirapina Ecological Station with 2300 ha and Mata do Jacaré Ecological Station with $75 \mathrm{ha}$ ); and two Sustainable Use areas (Environmental Protection Areas of Corumbataí-Botucatu-Tejupá and of Ibitinga with 214,706.70 and 64,900 ha, respectively) (Figure 1). These protected areas occupy about 280,000 ha of the total area of both watersheds, but only 75,000 ha are related to natural vegetation and water resources [15].

The Jacaré-Guaçu River, with a 155 km long, begins between the São Carlos and Itirapina municipalities, while the Jacaré-Pepira River, with $174 \mathrm{~km}$ long, begins between the Brotas and São Pedro municipalities. The Jacaré-Guaçu and Jacaré-Pepira river mouth areas known as "Pantaninho" and "Varjão", respectively, comprise a wetland system (Figure 1), with remnants of natural vegetation in an advanced recovery stage, known as "Pantanal Paulista" [15].

The UGRH1 13 region (Figure 1) presents a Cwa climate, according to the Köppen-Geiger classification [16], with hot and humid summers and dry winters. In the driest month, rainfall is less than $30 \mathrm{~mm}$ and medium temperatures are above $22^{\circ} \mathrm{C}$ in the hottest months. Temperatures are lower than $18^{\circ} \mathrm{C}$ in the colder months. The annual rainfall average is 1500 to $2000 \mathrm{~mm}$ [15]. 


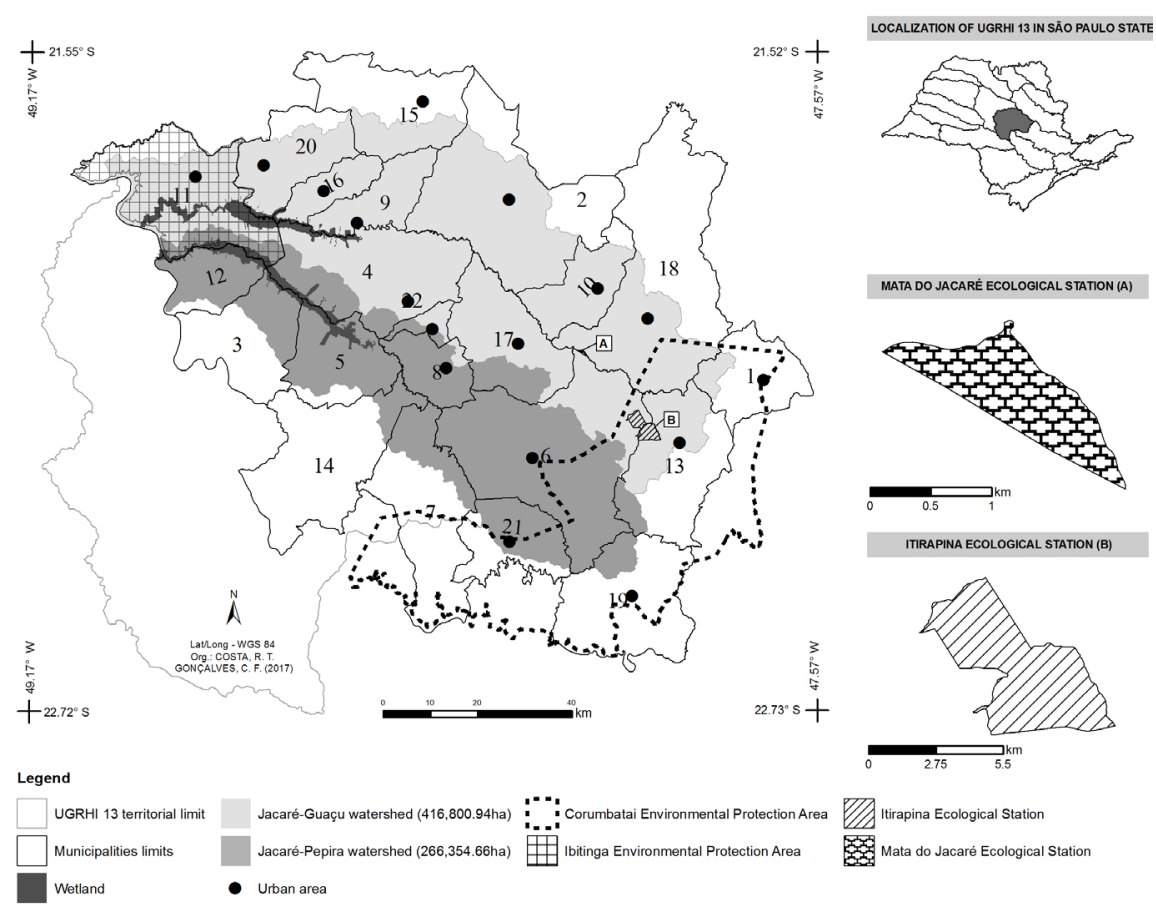

Figure 1. Location of the total area of study encompassing by the Jacaré-Guaçu and Jacaré-Pepira watersheds' limit, included on the boundaries of the Tiete-Jacaré watershed (UGRHI 13). The total area of study includes four protected areas (Corumbataí Environmental Protection Area; Ibitinga Environmental Protection Area; Mata do Jacaré Ecological Station and, Itirapina Ecological Station) and 22 territorial municipalities of the State of São Paulo (Brazil), 16 of which have their urban areas within the watershed boundaries.

Economic activities are related to sugarcane and citrus cultivation, extensive areas for pasture and reforestation of Pinus sp. and Eucalyptus sp. The industrial sector is related to citrus fruits and sugar cane processing, as well as paper, beverages, footwear, and textiles. Some municipalities have natural scenic features that provide ecotourism activities [15] [17].

\subsection{Land Use/Cover Dynamics}

Land use/cover dynamic were obtained based on screen digitizing of LandSat imagery, with $30 \mathrm{~m}$ spatial resolution, and a multispectral composite of three bands: near infrared, red and green wavelengths, over the 10-year period (2004-2014). The LandSat 5/TM and LandSat 8/OLI images, path 220 and 221, raw 75 and 76, were obtained on August 21 and 30, 2004 and August 1 and September 11, 2014, respectively. Image processing and georeferencing were carried out using ArcMap 10.2 software [18].

The land use/cover typology was discriminated by tone, texture and context criterias [19] [20], using on screen digitalizing. Each polygon of land use/cover was related to a previously first hierarchical level according to decreasing naturalness or increasing artificiality [21] [22]. The second hierarchical level described the typologies of land cover for each first level. 


\subsection{Naturalness Landscape Index}

The consequences that land use changes have had on landscape naturalness were analyzed based on the Urbanity Index (UI) [23]. For this procedure, land use was considered to be the main driver of change in the ecosystem [3]. This study did not consider indirect drivers related to demographic, economic, socio-political, cultural, religious, scientific or technological conditions [24] [25].

The UI [23] reflects the landscape naturalness condition and estimates (Equation (1)) the extent to which landscape is dominated by strongly human-altered systems [11]:

$$
\mathrm{UI}=\log _{10}\left[\frac{A+U}{F+W}\right]
$$

where $A$ denotes agricultural area, $U$ urban area, $F$ natural vegetation area, and $W$ aquatic environments and wetland area.

The spatial representation of the Urbanity Index was obtained through the commands Vector, Raster, Area and Image calculator in the IdrisiSelva software [26], rescheduled (fuzzy logic) for linear function, ranging between a minimum value $=0$ (zero) and maximum value $=1$ (one). This representation considers the maximum naturalness degree $(\mathrm{UI}=0)$ and the minimum naturalness degree $(\mathrm{UI}=1)$, which corresponds to human altered systems. High naturalness areas were defined by $\mathrm{UI} \leq 0.3$ values, whereas low naturalness areas were established by $\mathrm{UI} \geq 0.7$ values.

\subsection{Statistical Analysis}

The permutational multivariate analysis of variance (PERMANOVA) [27] [28] with Euclidian distance was used to test the null hypothesis of equal naturalness conditions between the Jacaré-Guaçu and Jacaré-Pepira watersheds (factors), and 2004 and 2014 (levels) [28]. It was randomly sampled 1000 points of UI spatial distribution for 2004 and 2014 (levels). The sampling was carried out using the "dismo" [29] and "raster" [30] packages for program R [31] and the PERMANOVA test was performed using the "vegan" package [32].

\section{Results and Discussion}

\subsection{Land Use/Cover Dynamics}

The watershed's landscape pattern, over a 10-year period (2004-2014), is determined by the presence of four land use classes (Figure 2), later categorized into 13 land cover types, in both watersheds total area: 1) Natural (Mixed Semi-deciduous Forests and Cerrado vegetation); 2) Anthropogenic agricultural (temporary cropping, continuous cropping, forestry, pasture, bare soil and rural infrastructure); 3) Anthropogenic non-agricultural (urban area, industry, mining and road networks); and 4) Aquatic environment (rivers, lakes, reservoirs, and wetland).

The territorial limit of watersheds represents a human space occupation resulting from developmental actions in the natural landscape. Agricultural and 


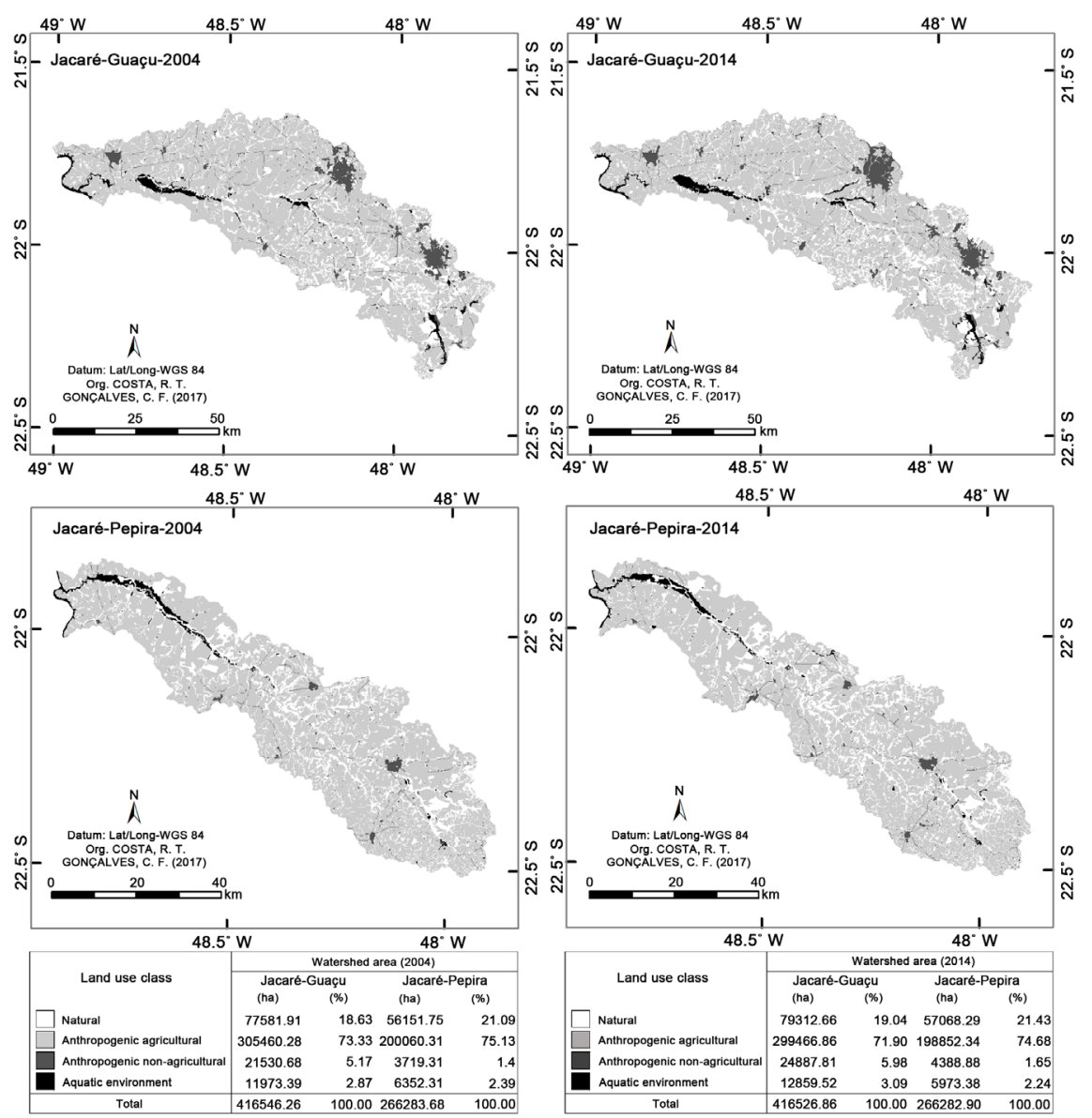

Figure 2. Land use classes (aquatic, natural, anthropogenic agricultural, and anthropogenic non-agricultural) and the respective areas (\%) for the Jacaré-Guaçu and Jacaré-Pepira watershed total areas, over the 10-year period (2004-2014).

forestry sectors act as main drivers of change concerning watersheds [17].

Natural land use in Jacaré-Guaçu and Jacaré-Pepira watersheds' total area, over the 10-year period (2004-2014), showed a minimal increase in change, equivalent to 173,075 and 91,654 ha, respectively, mainly due to the reduction of agricultural activities (Figure 2). Quantitatively, 30\% of natural vegetation has been proposed as a minimal limit to ensure sustainability in human-altered landscape [33]. Since natural areas occupy around $20 \%$ of the total area in each watershed (Figure 2), its continuous commitment is evidenced due to progressive anthropogenic agricultural and non-agricultural land use over the 10-year period (2004-2014).

Farming practices act as the main drivers of change as anthropogenic agricultural land use comprises over $70 \%$ of both watersheds total area. Anthropogenic agricultural land use was reduced around $1 \%$ compared to the Jacaré-Guaçu and Jacaré-Pepira watersheds (Figure 2), over the 10-year period (2004-2014).

Continuous cropping and forestry land cover reduced from $10.03 \%$ to $5.72 \%$ and $6.91 \%$ to $6.62 \%$, respectively, while bare soil increased by $22.96 \%$ to $31.80 \%$. The increase in the total area of bare soil, equivalent to $60,388.76$ ha, could be 
associated with the sugarcane harvest, which occurs between April and October in the state of São Paulo, as well as sugar cane expansion to produce ethanol [34] [35] [36].

The rate of land use change is increasing supporting biofuel feedstock production. In Brazil, sugarcane expansion is displacing degraded pastures, besides to impact soil physical quality due intensive mechanization [34]. In this case, human activities deplete natural capital stocks that support ecosystem services in society resulting in social problems, such as reducing the quality and availability of water in cities and biodiversity loss [5]. Sugar cane crops have also replaced citrus production areas, as a consequence of reduced production profitability [34]. This trend was also observed in the west of the state of São Paulo, where the soil fertility, climate and topography are favorable for citrus development [35].

Non-agricultural anthropogenic land use increased by 3,357.13 and 669.57 ha in the Jacaré-Guaçu and Jacaré-Pepira watersheds' total area, respectively (Figure 2), over the 10-year period (2004-2014). Increased urbanization area follows the number of inhabitants in 22 municipalities located at watershed boundaries, which increased from about 766,757 to 892,487 over the 10 -year period (2000-2010), representing an average of 5700 inhabitants per municipality [37] [38].

The aquatic environment showed an increase of $0.22 \%$, equivalent to 886.13 ha, of Jacaré-Guaçu watershed total area, and a decrease of $0.15 \%$, equivalent to 378.93 ha, of Jacaré-Pepira watershed total area (Figure 2), over the 10-year period (2004-2014). The reduction of the aquatic environment area may be associated with an atypical drought which occurred in 2014. In the normal dry season, from April to September, the water stored in groundwater supplies the springs keeping a perennial flow of the reservoirs, as well as the wetland continuity.

High temperatures, even in autumn 2014 and a shortage of rainfall induced rapid evaporation of soil moisture. During the dry season, a lack of rainfall and the water demand for public supply, together with high water transpiration in the soil and absorption of minimum reserves by the vegetation, caused a reduction in the water sources level. However, in the study area, the natural vegetation and the extent of flooded area did not change, showing a dependence of water that supplies the availability reservoir. The natural vegetation surrounding the Jacaré-Guaçu and Jacaré-Pepira wetland areas, known as "Pantanal Paulista", can use part of the stored water in the dry season, preventing water evaporation. However, when there are extreme cases of a lack of water, the vegetation competes with reservoirs in the water reserve.

\subsection{Naturalness Landscape Index}

Naturalness landscape refers to the natural capital stock which provides ecosystem services [8] [39]. The naturalness changes in the Jacaré-Guaçu and Jacaré- 
Pepira watershed areas, over the 10-year period (2004-2014), are shown in Figure 3. High naturalness areas correspond to UI values $\leq 0.3$, whereas low naturalness areas correspond to UI values $\geq 0.7$.

The UI values for the total area of both watersheds (Figure 4(a) and Figure 4(b)) showed a significantly higher anthropogenic interference with the commitment of the natural vegetation to ensure scenarios for biodiversity conservation and ecological sustainability for 2014 compared to $2004(\mathrm{~F}=4.6117, \rho=$ $0.026)$

Lower UI values (UI $\leq 0.3$ ) showed that around $15 \%$ of the total area of watersheds are related to higher naturalness, while higher UI values (UI $\geq 0.7$ ) showed that around $10 \%$ of the total area of watersheds are related to lower naturalness over the 10-year period (2004-2014) (Figure 3 and Figure 4(a) and Figure 4(b)).
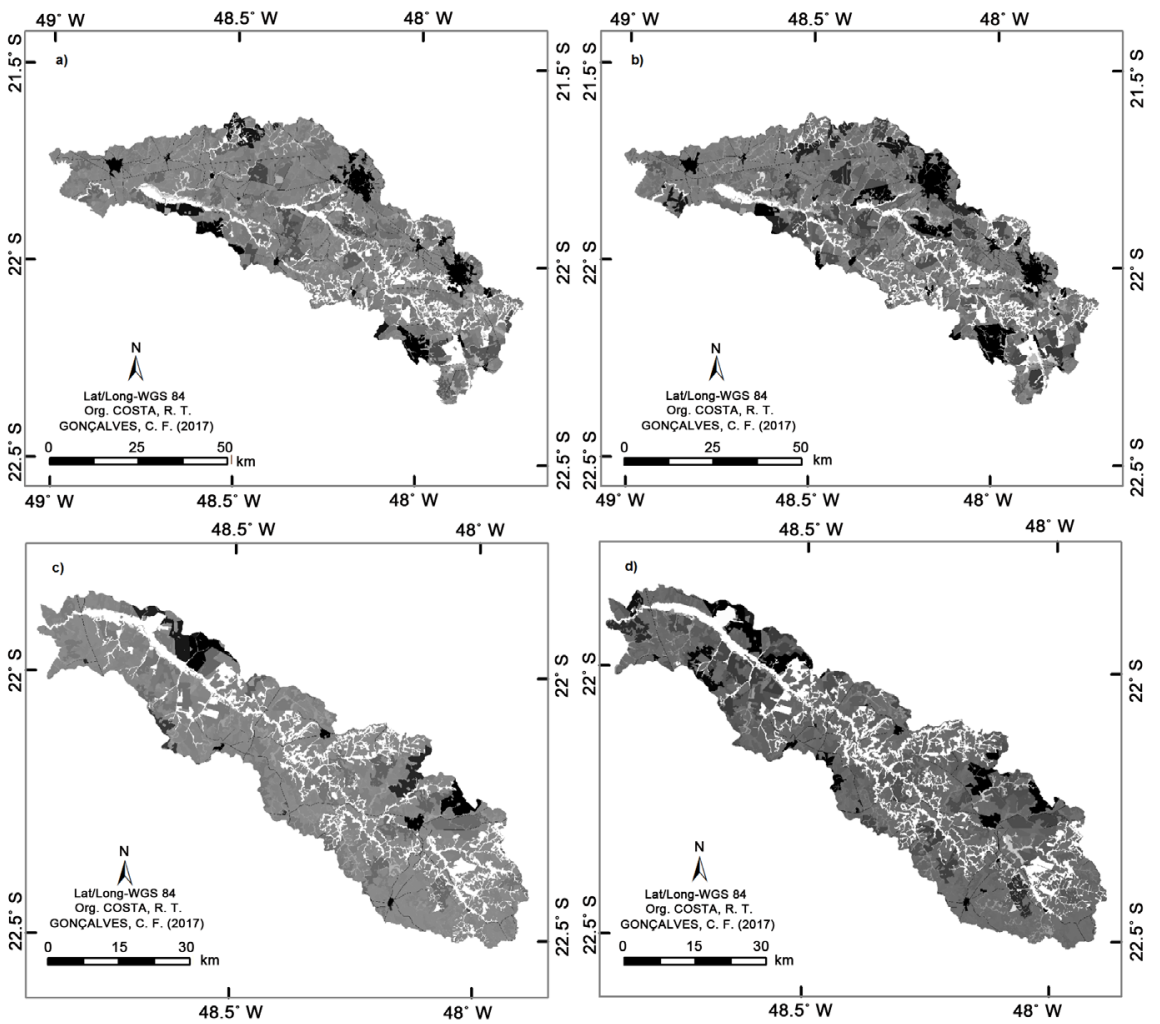

Urbanity Indicator (UI)

Value
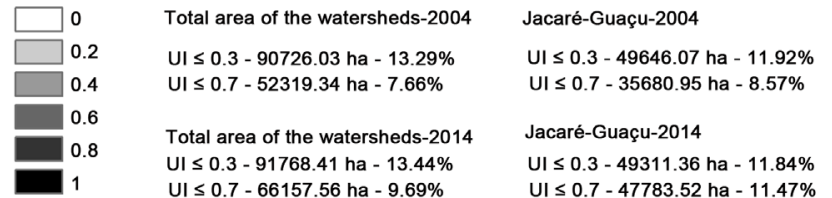

Jacaré-Pepira-2004

UI $\leq 0.3$ - 41075.82 ha $-15.43 \%$ U $\leq 0.7-16648.74$ ha $-6.25 \%$

Jacaré-Pepira-2014

UI $\leq 0.3-42455.34$ ha $-15.95 \%$ UI $\leq 0.7$ - 18369.18 ha $-6.90 \%$

Figure 3. Spatial representation of Urbanity Index (UI) values in the Jacaré-Guaçu and Jacaré-Pepira watershed areas over the 10-year period (2004-2014). (a) The Jacaré-Guaçu watershed, 2004; (b) The Jacaré-Guaçu watershed, 2014; (c) The Jacaré-Pepira watershed, 2004; (d) The Jacaré-Pepira watershed, 2014. UI values $\leq 0.3$ corresponding to high naturalness; UI values $\geq 0.7$ corresponding to low naturalness. 


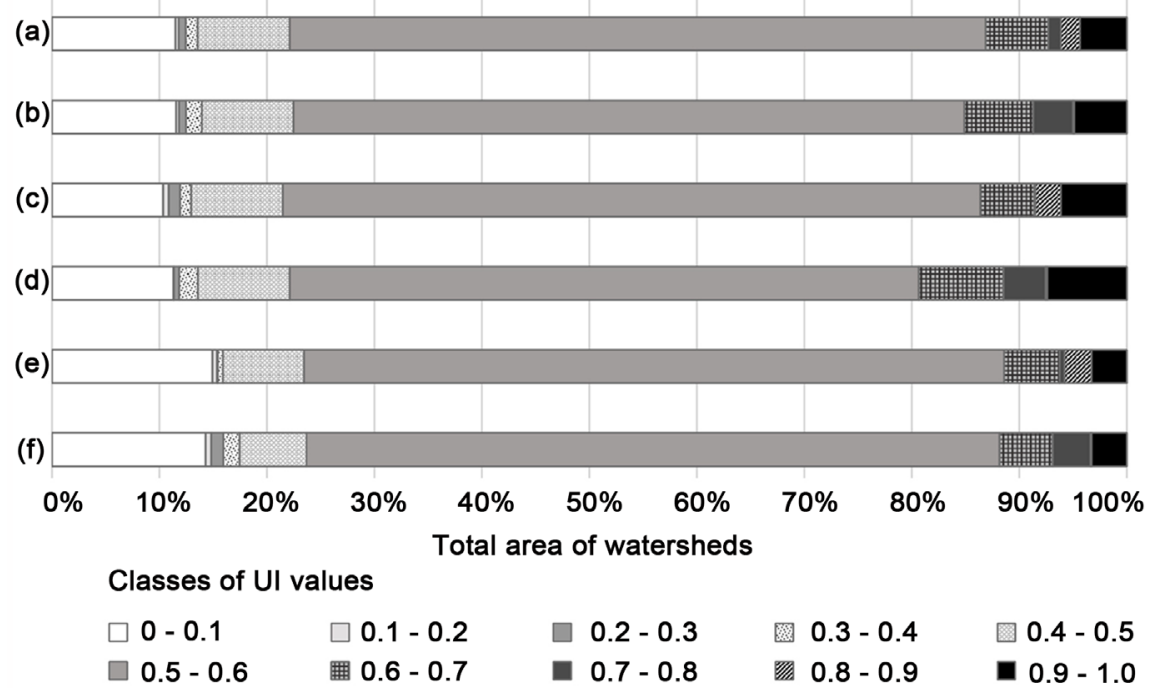

Figure 4. Percentages of total area of study encompassing the Jacaré-Guaçu and Jacaré-Pepira watersheds' area in relation to the Urbanity Index (UI) values: (a) total area of the Jacaré-Guaçu and Jacaré-Pepira watersheds in 2004; (b) total area of the JacaréGuaçu and Jacaré-Pepira watersheds in 2014; (c) total area of the Jacaré-Guaçu watershed in 2004; (d) total area of the Jacaré-Guaçu watershed in 2014; (e) total area of the Jacaré-Pepira watershed in 2004; (f) total area of the Jacaré-Pepira watershed in 2014.

The naturalness condition between both watersheds showed a significant difference in $2004(\mathrm{~F}=13.462, \rho=0.002)$, but were not statistically different in $2014(\mathrm{~F}=0.2587, \rho=0.624)$ (Figures $4(\mathrm{c})$-(f)). The Jacaré-Guaçu watershed showed greater impairment of naturalness with a higher extent of critical naturalness area (UI $\geq 0.7$ ), and a lower extent of high naturalness area (UI $\leq 0.3$ ), $8.57 \%$ and $11.92 \%$, respectively, when compared to the Jacaré-Pepira watershed (6.25\% and $15.43 \%$, respectively) in 2004 (Figure 3).

The Jacaré-Guaçu watershed showed no significant difference in the UI values $(\mathrm{F}=2.8266, \rho=0.106)$ from 2004 to 2014 (Figure 4(c) and Figure 4(d)). However, high naturalness areas corresponding to UI $\leq 0.3$ decreased $0.08 \%$, whereas critical areas of naturalness (UI $\geq 0.7$ ) increased $2.90 \%$ (Figure 3 ) over the 10-year period (2004-2014).

The Jacaré-Pepira watershed showed a significant difference in the UI values $(\mathrm{F}=6.9579, \rho=0.012)$ from 2004 to 2014 with a higher naturalness commitment in 2014 due to the increase in the occupied area for classes of UI values higher than 0.3 and lower than 0.7 (Figure 4(e) and Figure 4(f)). High naturalness areas corresponding to UI $\leq 0.3$ increased $0.52 \%$ around 17,600 ha, whereas the critical areas of naturalness ( $\mathrm{UI} \geq 0.7$ ) increased $0.65 \%$ over the 10 -year period (2004-2014) (Figure 3).

The Urbanity Index values for the total area of the watersheds, which corroborate with the spatial distribution of biodiversity conservation scenarios, showed a significant increase in natural vegetation areas over the 10 -year period (2004-2014). This could be associated to a recovery of natural land use/cover and a reduction in the fragmentation of the natural vegetation process. This is 
particularly for municipalities that have land use/cover rules in their territorial limits to ensure the preservation of natural vegetation areas.

Despite the increase in natural vegetation areas, the sustainability conditions are not ensured for both watersheds due to the historical process of regional land use/cover by adopting non-sustainable practices. The result is a natural capital deficit framework currently below the minimum of carrying capacity necessary to ensure the stock of natural capital and ecosystem services for human welfare and economic development, mainly for the Jacaré-Guaçu watershed which shows a more critical situation due to natural capital loss.

This scenario makes it essential to know the amount of the remaining natural capital in both watersheds area, as well as the implementation of strategies to control or minimize the loss of habitat and local biodiversity. The question is what amount of natural capital should be remain under current trends and policies given trade-offs with economic development and agriculture. According a review carried out by [39] and [40] based on species of temperate areas, this amount can be considered a threshold of around $30 \%$ of remaining habitat, above which the effects of biodiversity loss would be due to habitat loss. Below this threshold, there may be a drastic effect on the spatial distribution of the habitat. This threshold has no empirical support, as shown by results obtained in tropical regions reporting fragmentation effects on the habitat loss process [41]. However, landscapes with less than $30 \%$ of natural habitat has evidenced only small and unconnected fragments, thus supporting impoverished communities and different taxonomic groups [42] [43].

Thus, the threshold of $30 \%$ could be considered as the lower natural capital limit for a landscape managed by man to balance economic use and biodiversity conservation [33]. However, even considering the area values of Legal Reserve and Permanent Protection Areas, the Jacaré-Guaçu and Jacaré-Pepira watersheds do not have a natural cover area above this threshold. Governmental initiatives are aligning to assist conservation efforts in expanding legally protected areas in the municipal territories inserted in both watersheds area. These regional strategies can support the complete set of ecosystem services and improve managed watershed sustainability.

\section{Conclusion}

Anthropogenic agricultural and non-agricultural land use/cover were the main driving forces considering the naturalness of the Jacaré-Guaçu and Jacaré-Pepira watersheds over the 10-year period (2004-2014) as a result of the regional economic development and population growth demands by resources and the remaining natural habitats. This anthropogenic pressure exerted on both watersheds, and it is essential to apply land use sustainability strategies for the conservation of the most representative forest remnants and native vegetation. These strategies comply the need of instruments that facilitate the integration of planning and monitoring of biodiversity in areas of outstanding environmental 
value, like wetlands and the four protected areas located within the Jacaré-Guaçu and Jacaré-Pepira watershed limits.

We conclude by considering that dynamics of land use/cover still acting from before 2004, as the main driver for Jacaré-Guaçu and Jacaré-Pepira watersheds to undergoing a quick transition from natural to cultural landscape. A more accurate scenario shows that both watersheds are currently threatened by unsustainable land use related to a quick anthropic occupation. This trend changes ecological sustainability, reducing the ecosystem's resilience, as well as ecosystem services provided by the different land use/cover that summarizes the most relevant economic and environmental issues of the territorial municipalities.

Naturalness scenarios in both watersheds showed spatial displacement, over the 10-year period (2004-2014), due to the fragmentation of natural vegetation induced by agricultural and non-agricultural anthropogenic land use/cover. The Jacaré-Guaçu watershed showed a higher impairment of the naturalness condition in 2004 compared to the Jacaré-Pepira watershed, resulting from the anthropic occupation over the 10-year period (2004-2014). This naturalness watersheds impairment comes from a time previous to 2004, without evidence of change in this trend.

These results have significant implications for the fast urbanizing municipalities in providing key information about long term land use impact on the watershed structure and function, making it possible for policy makers, scientists and stakeholders to identify, at a glance, land uses which are hindered or enhanced under various scenarios of land use change over the 10-year period, and making it possible to explore the trade-offs between them to improve watershed management.

Therefore, implementing ecological and economic zoning in the Jacaré-Guaçu and Jacaré-Pepira watersheds is essential to ensure the protection and conservation of water resources and ecological life-support systems, particularly in the municipalities that are located in their surroundings. This zoning would require the maintenance of sustainable land use to improve the well-being of the local population, looking for a balance between socio-economic development and environmental conservation.

\section{Acknowledgements}

Financial support was provided by the Coordination for the Improvement of Higher Education Personnel (CAPES) and the São Paulo Research Foundation (FAPESP).

\section{References}

[1] Lambin, E.F, Turner, B.L., Geist, H.J., et al. (2001) The Causes of Land-Use and Land-Cover Change Moving beyond the Myths. Global Environment Change, 11, 261-269. https://doi.org/10.1016/S0959-3780(01)00007-3

[2] Jones, L., Bertrand, N., Briquel, V., Omodei-Zorini, L., Contini, C., Helming, K., Farrington, J.H., Mossello, M.T., Wascher, D., Kienast, F. and de Groot, R. (2008) 
Land Use Functions-A Multifunctionality Approach to Assess the Impact of Land Use Changes and Land Use Sustainability. In: Helming, K., Pérez-Soba, M. and Tabbush, P., Orgs., Sustainability Impact Assessment of Land Use Change, Sprig Berlin Heidelberg, 375-404.

[3] MEA (2005) Ecosystems and Human Well-being: Biodiversity Synthesis. World Resources Institute, Washington DC.

[4] Bürgi, M., Hersperger, A.M. and Schneeberger, N. (2004) Driving Forces of Landscape Change-Current and New Directions. Landscape Ecology, 19, 857-868. https://doi.org/10.1007/s10980-004-0245-8

[5] Foley, J.A., Defries, R., Asner, G.P., et al. (2005) Global Consequences of Land Use. Science, 309, 570-574. https://doi.org/10.1126/science.1111772

[6] Beier, C.M., Patterson, T.M. and Chapin III, F.S. (2008) Ecosystem Services and Emergent Vulnerability in Managed Ecosystems: A Geospatial Decision-Support Tool. Ecosystems, 11, 923-938. https://doi.org/10.1007/s10021-008-9170-z

[7] Grimm, N.B., Faeth, S.H., Golubiewski, N.E., et al. (2008) Global Change and the Ecology of Cities. Science, 319, 756-760. https://doi.org/10.1126/science.1150195

[8] Winter, S. (2012) Forest Naturalness Assessment as a Component of Biodiversity Monitoring and Conservation Management. Forestry, 85, 293-304. https://doi.org/10.1093/forestry/cps004

[9] Wittmann, F., Householder, E., Wittmann, A.O., et al. (2015) Implementation of the Ramsar Convention on South American Wetlands: An Update. Research and Reports in Biodiversity Studies, 4, 47-58. https://doi.org/10.2147/RRBS.S64502

[10] Nagendra, H., Munroe, D.K. and Southworth, J. (2004) From Pattern and Process: Landscape Fragmentation and the Analysis of Land Use/Cover Change. Agriculture, Ecosystem and Environment, 101, 111-115. https://doi.org/10.1016/j.agee.2003.09.003

[11] Wrbka, T., Erb, K.H., Schulz, N.B., Peterseila, J., Hahna, C. and Haberl, H. (2004) Linking Pattern and Process in Cultural Landscapes. An Empirical Study Based on Spatially Explicit Indicators. Land Use Policy, 21, 289-306. https://doi.org/10.1016/j.landusepol.2003.10.012

[12] Fushita, A.T., Santos, J.E., Reis, R.R. and Faresin, L. (2013) Satellite Image Classification for Land Use and Urbanity Monitoring: A Comparative Analysis. In: Santos, J.E. and Zanin, E.M., Org., Faces of Landscape Polysemy. Ecology, Planning and Perception, Vol. 5, Rima, São Carlos, 229-240.

[13] Dewan, A.M., Yamaguchi, Y. and Rahman, M.Z. (2012) Dynamics of Land Use/Cover Changes and the Analysis of Landscape Fragmentation in Dhaka Metroploitan, Bangladesh. GeoJournal, 77, 315-330. https://doi.org/10.1007/s10708-010-9399-x

[14] Ribeiro. C.A.A.S., Varella, C.A.A., Sena Jr., D.G. and Soares, V.P. (2000) Geographic Information System. In: Borem, A., et al., Eds., Precisionagriculture, Viçosa, MG, 380-407.

[15] Tietê-Jacaré Watershed Committee (2015) Water Resources Status Report 2015. http://www.sigrh.sp.gov.br/cbhtj/documentos

[16] Peel, M.C., Finlayson, B.L. and Mcmahon, T.A. (2007) Updated World Map of the Koppen-Geiger Climate Classification. Hydrology and Earth System Sciences Discussions, European Geosciences Union, 11, 1633-1644. https://doi.org/10.5194/hess-11-1633-2007

[17] PDRF-TJ (2016) Master Plan for Forest Restoration for Water Production and Preservation of Biodiversity of UGRHI-Tietê-Jacaré. Report on the Second Stage. 
http://pdrf-tiete-jacare.webnode.com

[18] ESRI (2013) ARCMAP. ArcGIS. 10.2. Environmental Systems Research Institute, Redlands, California.

[19] Crosta, A.P. (1992) Digital Processing of a Remote Sensing Image. 3rd Edition, IG/UNICAMP, Campinas.

[20] Moreira, M.A. (2011) Remote Sensing Fundaments and Application Methods. 4th Edition, UFV, Brasil.

[21] IBGE-Brazilian Institute of Geography and Statistics (2013) Land Use Technical Guide. 3rd Edition, IBGE.

[22] Haber, W. (1994) System Ecological Concepts for Environmental Planning. In: Haber, W., Ed., Ecosystem Classification for Environmental Management, Springer, The Netherlands, 49-67. https://doi.org/10.1007/978-94-017-1384-9_3

[23] O’Neill, R.V., Krummel, J.R., Gardner, R.H., Sugihara, G., Jackson, B., De Angelis, D.L., Milne, B.T., Turner, M.G., Zygmunt, B., Christensen, S.W., Dale, V.H. and Graham, R.L. (1988) Indices of Landscape Pattern. Landscape Ecology, 3, 153-162. https://doi.org/10.1007/BF00162741

[24] Nelson, G.C., Bennett, E., Berhe, A.A., et al. (2006) Anthropogenic Drivers of Ecosystem Change: An Overview. Ecology and Society, 11, 29.

https://doi.org/10.5751/ES-01826-110229

[25] Pereira, H.M., Leadley, P.W., Proença, V., Alkemade, R., Scharlemann, J.P.W., Fernandez-Manjarrés, J.F., Araújo, M.B., Balvanera, P., Biggs, R., Cheung, W.W., Chini, L., Cooper, H.D., Gilman, E.L., Guénette, S., Hurtt, G.C., Huntington, H.P., Mace, G.M., Oberdorff, T., Revenga, C., Rodrigues, P., Scholes, R.J., Sumaila, U.R. and Walpole, M. (2010) Scenarios for Global Biodiversity in the 21st Century. Science, 330, 1496-1501. https://doi.org/10.1126/science.1196624

[26] Eastman, J.R. (2012) IDRISI Selva. Clark University, Worcester.

[27] Anderson, M.J. (2001) A New Method for Non-Parametric Multivariate Analysis of Variance. Austral Ecology, 26, 32-46.

[28] Anderson, M.J. (2005) Permutational Multivariate Analysis of Variance. Department of Statistics, University of Auckland, Auckland.

[29] Hijmans, R.J., Phillips, S., Leathwick, J. and Elith, J. (2014) Dismo: Species Distribution Modeling. http://CRAN.R-project.org/package=dismo

[30] Hijmans, R.J. (2016) Raster Geographic Data Analysis and Modeling. https://cran.r-project.org/web/packages/raster/index.html

[31] R CORE TEAM (2014) R: A Language and Environment for Statistical Computing. R Foundation for Statistical Computing, Vienna.

[32] Oksanen, O., Blanchet, F.G., Kindt, R., et al. (2016) Vegan: Community Ecology Package. R Package Version 2.3-5. http://CRAN.R-project.org/package=vegan

[33] Metzger, J.P. (2010) The Forest Code Has a Scientific Basis? Nature \& Conservation, 8, 92-99. https://doi.org/10.4322/natcon.00801017

[34] Torquato, S.A. (2006) Sugar Cane for Industry: How Much Will Grow. Analysis and Indicators of Agribusiness, 1, 10.

[35] Cherubin, M.R., Karlen, D.L., Franco, A.L.C., et al. (2016) Soil Physical Quality Response to Sugarcane Expansion in Brazil. Geoderma, 267, 156-168. https://doi.org/10.1016/j.geoderma.2016.01.004

[36] Durigan, G., Siqueira, M.F.D. and Franco, G.A.D.C. (2007) Threats to the Cerrado remnants of the State of São Paulo, Brazil. Scientia Agricola, 64, 355-363. https://doi.org/10.1590/S0103-90162007000400006 
[37] IBGE (2000) Demographic Census.

https://www.ibge.gov.br/estatisticas-novoportal/sociais/populacao/9663-censo-dem ografico-2000.html

[38] IBGE (2010) Demographic Census. http://www.censo2010.ibge.gov.br

[39] Mäler, K.-G., Aniyar, S. and Jansson, Å. (2008) Accounting for Ecosystem Services as a Way to Understand the Requirements for Sustainable Development. Proceedings of the National Academy of Sciences, 105, 9501-9506. https://doi.org/10.1073/pnas.0708856105

[40] Andrén, H. (1994) Effects of Habitat Fragmentation on Birds and Mammals in Landscape with Different Proportions of Suitable Habitat: A Review. Oikos, 71, 355-366. https://doi.org/10.2307/3545823

[41] Fahrig, L. (2003) Effects of Habitat Fragmentation on Biodiversity. Annual Review of Ecology, Evolution and Systematic, 34, 487-515. https://doi.org/10.1146/annurev.ecolsys.34.011802.132419

[42] Develey, P.F. and Metzger, J.P. (2006) Emerging Threats to Birds in Brazilian Atlantic Forests: The Roles of Forest Loss and Configuration in a Severely Fragmented Ecosystem. In: Laurance, W.F. and Peres, C.A., Eds., Emerging Threats to Tropical Forests, University of Chicago Press, Chicago, 269-290.

[43] Martensen, A.C., Pimentel, R.G. and Metzger, J.P. (2008) Relative Effects of Fragment Size and Connectivity on Bird Community in the Atlantic Rain Forest: Implications for Conservation. Biological Conservation, 141, 2184-2192.

https://doi.org/10.1016/j.biocon.2008.06.008 